\section{Neuroscience gears up for duel on the issue of brain versus deity}

SIR - The argument over evolution versus intelligent design, discussed in your News story "Day of judgement for intelligent design" (Nature 438, 267; 2005), is a relatively small-stakes theological issue compared with the potential eruption in neuroscience over the material nature of the mind.

Siding with evolution does not really pose a serious problem for many deeply religious people, because one can easily accept evolution without doubting the existence of a non-material being. On the other hand, the truly radical and still maturing view in the neuroscience community that the mind is entirely the product of the brain presents the ultimate challenge to nearly all religions.

The slow ramping up of this debate, from Descartes' dualism in the seventeenth century to the neurophilosopher materialists claims of victory today, is about to spill over from an esoteric mind-brain debate to the divisive question of whether a product of the mind, such as God, can have any traditionally valid existence whatsoever.

The debate becomes whether a deity, on one hand, stems from human imagination or biological drive or, on the other hand, has an authentic existence that the brain has evolved to perceive.

The reappearance of dualism brings back dusty old memories oflong-ago battles that may now need to be refought. As we saw from the media ruckus raised by the Dalai Lama's address to November's Society for Neuroscience meeting in Washington DC (even if this did turn down to a rather low simmer on site), the potential for impassioned disagreement exists.

The matter now stands at an intellectual impasse, waiting for an issue around which polarized views will crystallize. We can expect some heady days.

Kenneth S. Kosik

Neuroscience Research Institute,

Department of Molecular and Cellular and

Developmental Biology, Bio II,

University of California, Santa Barbara,

Califomia 93106-5060, USA

\section{Testing is necessary on animals as well as in vitro}

SIR - Your News Feature ${ }^{\alpha}$ More than a cosmetic change" (Nature 438, 144-146; 2005) includes an emotive photograph showing the heads of six white rabbits, immobilized to have substances dropped into their eyes, with the caption ${ }^{\alpha}$ Tests that put chemicals into the eyes of rabbits have changed little since the $1940 \mathrm{~s}^{\mathrm{x}}$.
This is not true, at least as far as Britain is concerned. The Home Office, which is responsible for regulating experiments on living animals in Britain, issued guidelines in 1987 for eye irritation/corrosion tests (the Draize test), designed to reduce the pain and injury the test may cause. For example, a substance expected from its chemical nature to be seriously painful must not be tested in this way; the test is permissible only if the substance has already been shown not to cause pain when applied to skin, and in vitro pre-screening tests are recommended, such as a test on an isolated and perfused eye. Permission to carryout the test on several animals is given only if the test has been performed on a single animal and a period of 24 hours has been allowed for injury to become evident.

The interesting News Feature in which this photograph appears is unduly dismissive of experiments on living animals. What are the alternatives? The possibilities are either to stop the development of new drugs for human and veterinary use, or to put new drugs on the market without testing them on living animals, or to test new drugs on humans without previous testing on other animals. Few people would be prepared to accept any of these.

To speak of in vitro tests as 'alternatives' to testing on living animals is misleading: both are necessary. It is impossible to imitate in vitro the unimaginable complexity of a human being or indeed of any mammal. In vitro tests on bacterial cultures and tissue cultures are necessary in the early stages of testing the very large numbers of substances that are synthesized in order to produce a single drug for use on humans. These tests eliminate all but a very few of those substances, and only those few are candidates for testing on living animals.

Andrew Huxley

Trinity College, Cambridge CB2 1TQ, UK

\section{Animal-rights extremists lose public support}

SIR - I am disappointed at the negative tone of your recent News stories ${ }^{\alpha} \mathrm{UK}$ animal labs still under siege ${ }^{\text {" }}$ (Nature 438, 716; 2005) and "Animal-rights militancy exported to US and Europe" (Nature 438, 717; 2005). The situation in the United Kingdom is indeed serious, but not nearly as grim as you suggest.

UK Home Office figures for 2003 and 2004 show that the number of animal experiments in this country is rising slightly, and since then at least two additional large-scale transgenic-animal laboratories have opened. We are all aware of the setbacks, but the overall picture is hardly that of animal research being driven out. It is true that animal-rights groups have won a few victories in Britain during the last few years, but they have done so at the cost of alienating the vast majority of the general public. A recent ICM opinion poll (see www. icmresearch.co.uk/reviews/latest-polls.asp) indicates that a clear majority of UK adults support the use of animals for medical research. During the past decade - which has seen animal-rights extremist campaigns of unprecedented scale, ferocity and sophistication - public and media support for the use of animals in research has in fact increased significantly.

The University of Oxford, with the support of the UK government and the overwhelming support of its own student body (www. cherwell.org/show_article.php?id=3868), is willing to face down the extremists.

These are strong indications that the animal-rights extremist campaign has reached its high-water mark and that the tide is now turning against it. The victory against extremism is there for the taking, but the scientific community must learn to reach up and grab it. That means refusing to be intimidated, standing up for our science and, perhaps most important, staying positive.

P. Browne

Address provided

\section{Why should child care be seen as a women's issue?}

SIR - It has been a few decades since families started raising their daughters to have high personal and professional ambitions. But still only a small minority of women remain in science after their postdoctoral phase mainly those who have postponed or forgone motherhood, or are among the lucky few with access to high-quality affordable child care.

The fact that the issue of childcare availability is discussed in relation to women's careers (Nature 437, 296 and 446-447; 2005), instead of young scientists' careers in general, speaks for itself of the bias regarding the role of women in the family and in the workplace.

If women are to share positions that were traditionally occupied almost exclusively by men, what we need is not just affordable child care but a new social 'family contract,' coherent with expectations about women's self-fulfilment and the maintenance of the family as an important institution.

\section{Mari ia José Hōtzel}

Laboratório de Etologia Aplicada, Departamento de Zootecnia e Desenvolvimento Rural, Universidade Federal de Santa Catarina, Florianópolis, SC 88.034-001, Brazil

Contributions to Correspondence may be submitted to corres@nature.com.

They should be no longer than $\mathbf{5 0 0}$ words and should be signed by no more than three authors; preferably by one. 